\title{
PENGARUH PENGUNGKAPAN CORPORATE SOCIAL RESPONSIBILITY PADA ABNORMAL RETURN
}

\author{
Made Erika Krisdiyanti Putri ${ }^{1}$ \\ I Gusti Ayu Nyoman Budiasih ${ }^{2}$
}

\author{
${ }^{1}$ Fakultas Ekonomi dan Bisnis Universitas Udayana, Bali, Indonesia \\ e-mail: erikakdy13@yahoo.com \\ ${ }^{2}$ Fakultas Ekonomi dan Bisnis Universitas Udayana, Bali, Indonesia
}

\begin{abstract}
The population in this study were all manufacturing companies listed on the Stock Exchange from 2013 - 2017. The sampling technique was carried out using a purposive sampling method that is non-random selection of information obtained using certain considerations. The research sample consisted of 60 manufacturing companies listed on the Indonesia Stock Exchange (IDX) which were sampled during the 2013-2017 period. The measurement of CSR disclosure is based on the Global Reporting Initiative (GRI) -G4 of 91 CSR disclosure index items. Whereas, abnormal returns are calculated using the market adjusted model. The results show that disclosure of CSR affects abnormal returns. Research shows that investors consider CSR information to make decisions. The implication of this research is that investors care about corporate social responsibility in making decisions to invest.
\end{abstract}

Keywords: abnormal return; CSR; ROE; PBV disclosure

\begin{abstract}
ABSTRAK
Populasi dalam penelitian ini adalah seluruh perusahaan manufaktur yang terdaftar di BEI dari tahun 2013 - 2017. Teknik pengambilan sampel dilakukan dengan menggunakan metode purposive sampling yaitu pemilihan secara tidak acak yang informasinya diperoleh dengan menggunakan pertimbangan tertentu. Sampel penelitian terdiri dari 60 perusahaan manufaktur yang terdaftar di Bursa Efek Indonesia (BEI) yang menjadi sampel selama periode 2013-2017. Pengukuran pengungkapan CSR didasarkan pada Global Reporting Initiative (GRI)-G4 sebanyak 91 item indeks pengungkapan CSR. Sedangkan, abnormal return dihitung dengan menggunakan market adjusted model .Hasilnya menunjukkan bahwa pengungkapan CSR berpengaruh pada abnormal return. Penelitian menunjukkan bahwa investor mempertimbangkan informasi CSR untuk membuat keputusan. Implikasi dari penelitian ini adalah bahwa investor peduli dengan tanggung jawab sosial perusahaan dalam mengambil keputusan untuk berinvestasi
\end{abstract}

Kata kunci: abnormal return; pengungkapan CSR; ROE; PBV.

\section{PENDAHULUAN}

Pelaporan keuangan merupakan salah satu wujud pertanggungjawaban manajemen atas pengelolaan sumber daya perusahaan kepada pihak-pihak yang berkepentingan terhadap perusahaan selama perioda tertentu. Perusahaan yang mempublikasikan laporan keuangan secara teoritis dan empiris telah menyebabkan 
perubahan harga saham, dalam hal ini pasar modal merupakan sarana mobilitas dana yang bersumber dari masyarakat dan menyalurkan dana tersebut keberbagai sektor yang membutuhkannya melalui investasi (Mujiani, 2017). Investasi pada saham merupakan suatu alternative investasi yang cukup menarik karena seorang investor dapat berspekulasi dan berharap bahwa saham yang dimilikinya saat itu akan mendatangkan keuntungan. Ketika return yang didapat investor tidak sesuai dengan pengharapannya maka terjadi abnormal return.

Abnormal return adalah return yang didapat investor yang tidak sesuai dengan pengharapan. Sidik (2008) menyatakan bahwa pada umumnya investor mengharapkan return normal yang proposional dengan pengorbanan yang dikeluarkan. Namun bagi investor yang canggih (sophisticated), dimana strategi investasi yang dilakukan lebih agresif atau memiliki resiko tinggi dapat memperoleh return tidak normal. Return ini disebut abnormal return, yang dihitung dari selisih antara return yang sesungguhnya terjadi (actual return) dengan return yang diharapkan oleh investor (expected return). Abnormal return akan positif jika return yang didapatkan lebih besar dari return yang diharapkan atau return yang dihitung. Sedangkan abnormal return akan negative jika return yang didapat lebih kecil dari return yang diharapkan atau return yang dihitung (Hartono, 2016). Abnormal return dapat terjadi karena adanya kejadian-kejadian tertentu, misalnya hari libur nasional, awal bulan, awal tahun, kejadian-kejadian yang luar biasa, stock split, penawaran perdana saham dan lain-lain.

Riset yang dilakukan oleh Cheng dan Christiawan pada tahun 2011 mengenai fenomena abnormal return dengan adanya informasi Corporate Social 
Responsibility yang diperoleh dari laporan tahunan perusahaan yang terdaftar di Bursa Efek Indonesia pada tahun 2007-2009 dalam sektor industri yang berhubungan dengan sumber daya alam yakni Sektor Agriculture, Sektor Pertambangan dan Sektor Industri Dasar dan Kimia. Terdapat 40 perusahaan dalam penelitian tersebut diantaranya terdiri dari 10 perusahaan industry Agriculture, 11 perusahaan pertambangan dan 20 perusahaan kimia dasar. Hasil penelitian tersebut diperoleh bahwa pengungkapan Corporate Social Responsibility akan direspon oleh pasar ditandai dengan adanya abnormal return.

Abnormal return dapat digunakan sebagai alat ukur untuk melihat reaksi investor, adapun reaksi investor beragam atas sebuah informasi. Informasi merupakan kebutuhan yang mendasar bagi para investor dan calon investor, karena dengan adanya informasi yang lengkap, akurat, relevan dan tepat waktu memungkinkan para investor dapat melakukan pengambilan keputusan secara rasional sehingga hasil yang diperoleh sesuai dengan yang diharapkan. Salah satu informasi yang sering diminta untuk diungkapkan oleh perusahaan saat ini adalah informasi tentang Corporate Social Responsibility. Corporate Social Responsibility merupakan keseluruhan hubungan perusahaan dengan semua stakeholder-nya, yang meliputi konsumen, karyawan, masyarakat, pemilik/investor, pemerintah, dan pemasok (Yulia dan Wahidahwati, 2013).

Corporate Social Responsibility didefinisikan sebagai komitmen berkesinambungan dari kalangan bisnis untuk berperilaku etis dan member kontribusi bagi pembangunan ekonomi, seraya meningkatkan kualitas kehidupan karyawan dan keluarganya, serta komunitas lokal dan masyarakat luas pada 
umumnya menurut World Business Councilfor Sustainable Development (Suharto, 2010). Konsep tentang Corporate Social Responsibility muncul ketika kesadaran akan sustainability jangka panjang perusahaan sangat penting. Pada dasarnya pengungkapan tanggungjawab sosial perusahaan bertujuan untuk memperlihatkan kepada masyarakat tentang aktivitas sosial yang dilakukan oleh perusahaan dan pengaruhnya kepada masyarakat (Atiqah, 2016). Penerapan Corporate Social Responsibility dipercaya dapat meningkatkan kinerja perusahaan, para investor cenderung menanamkan modal kepada perusahaan yang melakukan kegiatan Corporate Social Responsibility (Cheng dan Christiawan, 2011). Dengan demikian pengungkapan tanggungjawab sosial dapat dianggap sebagai strategi bisnis untuk menarik investor. Muid (2011) menjelaskan teori stakeholders yang menyatakan bahwa pengungkapan tanggungjawab sosial oleh perusahaan dilakukan sebagai upaya untuk memenuhi keinginan stakeholders. Teori stakeholder adalah teori yang menyatakan bahwa perusahaan bukanlah entitas yang hanya beroperasi untuk kepentingan sendiri, namun harus memberikan manfaat kepada seluruh stakeholder-nya (Ghozali dan Chariri, 2007). Pengungkapan Corporate Social Responsibility yang dilakukan perusahaan diharapkan mampu memberikan signal dan dapat meningkatkan nilai perusahaan dimata investor. Teori signaling adalah teori yang menjelaskan mengenai sinyal-sinyal informasi yang dibutuhkan oleh investor untuk mempertimbangkan dan menentukan apakah para investor akan menanamkan sahamnya atau tidak pada perusahaan yang bersangkutan (Indrawati, 2009). 
Informasi tentang laporan Corporate Social Responsibility dapat diperoleh melalui laporan tahunan yang dikeluarkan oleh perusahaan. Laporan tahunan memberikan gambaran tentang kinerja perusahaan secara komprehensif baik mengenai informasi keuangan maupun informasi non keuangan yang perlu diketahui oleh para pemegang saham, calon investor, pemerintah, atau bahkan masyarakat. Perhitungan abnormal return yang digunakan dalam penelitian ini adalah data tanggal publikasi laporan tahunan, harga pasar saham serta jumlah saham beredar. Oleh karena itu, terdapat variabel kontrol yang terdiri dari variabelvariabel yang mempengaruhi abnormal return selain variabel independen yaitu Corporate Social Responsibility. Dalam hal ini variabel yang digunakan sebagai variabel control adalah Return on Equity (ROE) dan Price to Book Value (PBV).

Variabel kontrol merupakan variabel yang dikendalikan sehingga pengaruh variabel bebas terhadap variabel terikat tidak dipengaruhi oleh faktor luar yang tidak diteliti. ROE adalah salah satu rasio profitabilitas yang digunakan investor ketika menganalisis suatu perusahaan. ROE menunjukan kemampuan perusahaan untuk menghasilkan laba bersih berdasarkan modalnya (Mamduh, 2009). Investor selalu berharap untuk mendapatkan ROE yang tinggi, akan tetapi harapan investor ini tidak selalu sesuai dengan kenyataannya karena adanya faktor resiko (Cheng dan Christiawan, 2011). ROE yang tidak sesuai dengan ekspektasi dari investor dapat membuat pasar bereaksi yang ditunjukan dengan adanya abnormal return. Menurut Cheng dan Christiawan (2011) perubahan ROE perusahaan akan mengakibatkan perubahan nilai perusahaan sehingga hal ini akan menimbulkan reaksi dari invetor yang tercermin pada abnormal return. Semakin tinggi $\mathrm{ROE}$ 
perusahaan dianggap sebagai kabar baik (good news) karena ROE yang besar berarti semakin besar peluang para investor untuk memperoleh laba bersih dari setiap modal yang diinvestasikan sehingga akan direspon positif oleh pasar yang tercermin dalam abnormal return. Sebaliknya, semakin rendah ROE perusahaan dianggap sebagai kabar buruk ( $b a d$ news) karena ROE yang rendah berarti semakin kecil peluang pemilik perusahaan memperoleh keuntungan dari laba bersih untuk setiap modal yang diinvestasikan sehingga akan direspon negatif oleh pasar.

Kenaikan atau penurunan PBV perusahaan memiliki kandungan informasi yang menimbulkan reaksi investor yang ditunjukan dengan abnormal return (Cheng dan Christiawan, 2011). PBV perusahaan yang tinggi menandakan bahwa perusahaan memiliki kinerja yang baik dalam arti mampu meningkatkan laba, meningkatkan harga saham atau menghasilkan produk yang berhasil sehingga hal ini akan direspon positif oleh invetor. Sedangkan, PBV perusahaan yang rendah menandakan perusahaan memiliki pertumbuhan yang rendah sehingga hal ini akan direspon negatif oleh pasar. Perusahaan yang memiliki kesempatan tumbuh yang tinggi diharapkan akan memberikan profitabilitas yang tinggi di masa depan, dan diharapkan laba lebih persisten. Perusahaan dengan PBV yang tinggi memungkinkan perusahaan mendapatkan atau menambah laba sehingga PBV perusahaan merupakan hal yang perlu dipertimbangkan oleh investor (Kastutisari dan Nurul, 2012). Semakin tinggi rasio ini berarti pasar mempercayai prospek perusahaan tersebut. Hal ini akan menjadi daya tarik bagi investor untuk membelinya. Sehingga permintaan akan saham tersebut akan naik, kemudian 
mendorong harga saham perusahaan tersebut naik. Jika harga saham naik, maka akan mempengaruhi abnormal return.

Undang-Undang No. 40 Tahun 2007 tentang Perseroan Terbatas pasal 74 menyatakan bahwa: Perseroan yang menjalankan usahanya dibidang dan atau berkaitan dengan sumber daya alam wajib melaksanakan tanggungjawab sosial dan lingkungan. Di Indonesia, permasalahan lingkungan akibat proses produksi perusahaan banyak ditemukan, hal ini sebagian besar disebabkan oleh perusahaan manufaktur karena memproduksi industri yang limbah yang dibuang atau bahan yang digunakan semakin merusak lingkungan sekitar. Masalah yang ditimbulkan perusahaan manufaktur mengakibatkan adanya aksi protes yang mengganggu operasi perusahaan yang dilakukan oleh berbagai pihak yang berkepentingan, baik yang bersifatinternal maupun bersifat eksternal. Dalam mengukur sejauh mana perusahaan melakukan tanggungjawab sosialnya, maka terdapat pedoman dari Global Reporting Initiative (GRI)-G4 sebanyak 91 item yang diluncurkan pada Mei 2013. Oleh sebab itu diteliti perusahaan manufaktur yang terdaftar di Bursa Efek Indonesia pada tahun 2013-2017.

Signalling theory (teorisinyal) digunakan untuk menjelaskan bahwa pada dasarnya suatu informasi dimanfaatkan perusahaan untuk member sinyal positif maupun negatef kepada pemakainya (Kastutisari dan Nurul, 2012). Suatu kejadian atau pesan dikatakan mengandung informasi jika pesan tersebut menyebabkan perubahan keyakinan penerima dan memicu tindakan tertentu (misalnya terefleksi dalam perubahan hargaatau volume saham di pasar modal), dimana tindakan tersebut dinyakini sebagai akibat informasi dalam kejadian atau pesan tersebut, 
maka dapat dikatakan bahwa informasi tersebut bermanfaat. Jadi dapat disimpulkan, sebuah informasi dapat dikatakan bermanfaat apabila informasi tersebut benar-benar atau seakan-akan digunakan dalam pengambilan keputusan oleh pemakai yang dituju, yang ditunjukkan adanya asosiasi antara peristiwa (event) dengan return, harga atau volume saham di pasar modal (Suwardjono, 2008).

Menurut Brigham dan Houston (2009) teori sinyal menjelaskan tentang bagaimana para investor memiliki informasi yang sama tentang prospek perusahaan sebagaimana perusahaan. Teori sinyal menyatakan bahwa pihak eksekutif perusahaan yang memiliki informasi lebih baik mengenai perusahaannya akan terdorong untuk menyampaikan informasi tersebut kepada calon investor dimana perusahaan dapat meningkatkan nilai perusahaan melalui pelaporannya dengan mengirimkan sinyal melalui laporan tahunannya (Kastutisari dan Nurul, 2012).

Pengungkapan Corporate Social Responsibility dalam annual report diharapkan mampu dijadikan sinyal oleh perusahaan ketika menarik minat investor untuk menanamkan dana pada saham perusahaan. Investor akan bereaksi positif apabila melihat perusahaan mengimplementasikan Corporate Social Responsibility. Hal inilah yang memotivasi perusahaan mencoba memberikan sinyal positif ketika mengungkapkan CSR.

Teori stakeholder adalah teori yang menyatakan bahwa perusahaan bukanlah entitas yang hanya beroperasi untuk kepentingan sendiri, namun harus memberikan manfaat kepada seluruh stakeholder-nya (Ghozali dan Chariri, 2007). Dengan demikian keberadaan suatu perusahaan sangatdipengaruhi oleh dukungan yang diberikan oleh stakeholders kepada perusahaan tersebut. 
Widjaja dan Pratama (2008) mendefinisikan stakeholders sebagai seseorang atau sekelompok orang yang memiliki satu atau lebih kepentingan (stake) yang berbeda dalam sebuah perusahaan. Stakeholders dapat diartikan juga sebagai setiap orang atau sekelompok orang yang dapat mempengaruhi atau dipengaruhi oleh tindakan, keputusan, kebijakan, praktik atau tujuan dari sebuah perusahaan. Stakeholders merupakan individu, sekelompok manusia, komunitas atau masyarakat baik secara keseluruhan maupun secara parsial yang memiliki hubungan serta kepentingan terhadap perusahaan.

Dengan mengetahuiapa yang diinginkan stakeholder maka manajer dapat merumuskan suatu strategi korporat yang fleksibel yang tidak hanya bisa mengakomodasi seluruh kepentingan stakeholder, tetapi juga tujuan akhir perusahaan. Salah satu pewujutan strategi korporat adalah dengan melaksanakan program Corporate Social Responsibility serta mengungkapkannya didalam laporan tahunan. Hal ini penting dilakukan karena investor sebagai stakeholder perlu mengevaluasi sejauh mana perusahaan telah melaksanakan perannya sesuai keinginan stakeholder.

\section{MenurutWorld Business Council for Sustainable Development} (dalamSuharto, 2010)menjelaskanCorporate Social Responsibility. Merupakan suatu komitmen berkelanjutan oleh dunia usaha untuk bertindak secara etis dan memberikan kontribusi kepada pengembangan ekonomi dari komunitas setempat ataupun masyarakat secara luas, bersamaan dengan peningkat antara hidup pekerjanya beserta seluruh keluarganya. Sedangkan, ISO (International Organization for Standardization) sebagai induk organisasi standarisasi 
internasional, beinisiatif mengundang berbagai pihak untuk membentuk tim (working group) yang membidani lahirnya panduan dan standarisasi untuk tanggungjawab sosial yang diberinama ISO 26000: Guidance Standard on Social Responsibility. Menurut ISO 26000 mengenai pedoman tanggungjawab sosial yang diresmikan November 2011, Corporate Social Responsibility adalah Tanggung jawab sebuah organisasi terhadap dampak-dampak dari keputusan-keputusan dan kegiatan-kegiatannya pada masyarakat dan lingkungan yang diwujudkan dalam bentuk perilaku transparan dan etis yang sejalan dengan pembangunan berkelanjutan dan kesejahteraan masyarakat; mempertimbangkan harapan pemangku kepentingan, sejalan dengan hukum yang ditetapkan dan norma-norma perilaku internasional; serta terintegrasi dengan organisasi secara menyeluruh. Perusahaan selain berorientasi terhadap laba, perusahaan juga bertanggungjawab terhadap masalah sosial yang ditimbulkan oleh aktivitas operasional yang dilakukan perusahaan dengan manajemen lingkungan sehingga tidak hanya terbatas pada orientasi kinerja keuangan perusahaan. Suharto (2010) menjelaskan Corporate Social Responsibility adalah operasi bisnis yang berkomitmen tidak hanya untuk meningkatkan keuntungan perusahaan secara finansial, melainkan pula untuk pembangunan sosial-ekonomi kawasan secara holistik, melembaga dan berkelanjutan. Pelaksanaan Corporate Social Responsibility merupakan hal yang sangat penting karena berkaitan dengan pembentukan citra positif perusahaan.

Pengungkapan Corporate Social Responsibility merupakan bagian dari akuntansi pertanggungjawaban sosial yang mengkomunikasikan informasi sosial kepada stakeholder. Menurut Guthrie dan Parker (1990) sebagaimana dikutip oleh 
Sayekti dan Ludovicus (2007), pengungkapan informasi CSR dalam laporan tahunan merupakan salah satu cara perusahaan untuk membangun, mempertahankan, dan melegitimasi kontribusi perusahaan dari sisi ekonomis dan politis. Selain itu juga, akuntansi pertanggungjawaban sosial dapat memberikan informasi mengenai sejauh mana organisasi atau perusahaan memberikan kontribusi positif maupun negative terhadap kualitas hidup manusia dan lingkungannya. Menurut Ghozali dan Chariri (2007), pengungkapan tanggungjawab sosial perusahaan merupakan proses yang digunakan oleh perusahaan untuk mengungkapkan informasi berkaitan dengan kegiatan perusahaan dan pengaruhnya terhadap kondisi sosial masyarakat dan lingkungan. Hal tersebut memperluas tanggungjawab organisasi dalam hal ini perusahaan, di luar perantara disionalnya untuk menyediakan laporan keuangan kepada pemilik modal, khususnya pemegang saham.

Tanggung jawab sosial perusahaan bersifat wajib bagi kriteria perusahaan tertentu seperti yang disebutkan dalam UU No. 40 Tahun 2007 tentang Perseroan Terbatas pasal 74 menyatakan bahwa: Perseroan yang menjalankan usahanya dibidang dan atau berkaitan dengan sumberdaya alam wajib melaksanakan tanggungjawab sosial dan lingkungan. Dan Tanggungjawab sosial dan lingkungan tersebut merupakan kewajiban perseroan yang dianggarkan dan diperhitungkan sebagai biaya perseroan yang pelaksanaanya dilakukan dengan memperhatikan kepatuhan dan kewajaran. Jika Perseroan yang tidak melaksanakan kewajiban tanggungjawab sosial akan dikenai sanksi sesuai dengan ketentuan peraturan perundangundangan. Selain perusahaan wajib melakukan kegiatan Corporate 
Social Responsibility, UU No. 40 Tahun 2007 pasal 66 ayat (2) tentang Perseroan Terbatas juga mewajibkan perusahaan untuk mengungkapkan aktivitas tanggung jawab sosialnya dalam laporan tahunan.

Standar pengungkapan Corporate Social Responsibility yang berkembang di Indonesia merujuk pada standar yang diterapkan GRI (Global Reporting Initiative). Standar GRI dipilih karena lebih memfokuskan pada standar pengungkapan sebagai kinerja ekonomi, sosial dan lingkungan perusahaan dengan tujuan untuk meningkatkan kualitas dan pemanfaatan sustainability reporting. Saatinistandar GRI versi terbaru adalah versi G4 yang diluncurkan pada Mei 2013. GRI-G4 menyediakan kerangka kerja yang relevan secara global untuk mendukung pendekatan yang terstandarisasi dalam pelaporan yang mendorong tingkat transparansi dan konsistensi yang diperlukan untuk membuat informasi yang disampaikan menjadi berguna dan dapatdipercaya oleh pasar dan masyarakat. Fitur yang ada di GRI-G4 menjadikan pedoman ini lebih mudah digunakan baik bagi pelapor yang berpengalaman dan bagi mereka yang baru dalam pelaporan keberlanjutan sektor apapun dan didukung oleh bahan-bahan dan layanan GRI lainnya. Dalam standar GRI-G4, indikator kinerja dibagi menjadi tiga komponen utama, yaitu ekonomi, lingkungan hidup dan sosial. Kategori sosial mencakup hak asasi manusia, praktik ketenagakerjaan dan lingkungan kerja, tanggungjawab produk dan masyarakat. Total indikator yang terdapat dalam GRI mencapai 91 item. Berdasarkan stakeholder theory, keberlanjutan hidup perusahaan bertumpu pada memuaskan semua stakeholder, yaitu baik dalam aspek ekonomi maupun non ekonomi (lingkungan dan sosial) yang diimplimentasikan dalam Corporate Social 
Responsibility di dalam annual report perusahaan. Searah dengan signaling theory dimana perusahaan dapat meningkatkan nilai perusahaan melalui pelaporannya dengan mengirimkan signal melalui laporan tahunannya, maka pengungkapan atau pelaporan aktivitas perusahaan yang berkaitandengan Corporate Social Responsibility adalah salah satu cara untuk mengirimkan sinyal kepada para pemangku kepentingan (stakeholders) dan pasar mengenai gambaran perusahaan di masa yang akan datang bahwa perusahaan memberikan garansi atas keberlangsungan hidup perusahaan dimasa yang akan datang.

Penelitian yang mendukung adanya hubungan antara Corporate Social Responsibility dengan abnormal return adalah penelitian yang dilakukan oleh Nurdin dan Cahyandito (2006) yang menunjukkan bahwa aktivitas CSR berpengaruh positif terhadap abnormal return yang menandakan bahwa investor mempertimbangkan informasi CSR untuk membuat keputusan. Penelitian dari Cheng dan Christiawan (2011) menunjukkan hasil penelitian untuk hipotesis pertama menunjukan bahwa pengungkapan informasi Corporate Social Responsibility berpengaruh signifikan terhadap abnormal return. Pengungkapan Corporate Social Responsibility yang dilakukan perusahaan memiliki kandungan informasi, sehingga investor akan bereaksi pada pengumuman itu. Kemudian penelitian yang diteliti oleh Anugrawati (2015) menunjukan bahwa hasil uji mendukung hipotesis bahwa pengungkapan Corporate Social Responsibility berpengaruh signifikan terhadap abnormal return.

Pengungkapan Corporate Social Responsibility diharapkan memiliki kandungan informasi, sehingga pasar atau investor akan bereaksi setelah 
pengumuman ituditerima. Signal positif ini diharapkan dapat menghasilkan respon positif dari pasar. Reaksi investor dapat diukur dengan menggunakan abnormal return. Dengan demikian, hipotesis yang dapat dibuat adalah:

$\mathrm{H}_{1}$ : Pengungkapan informasi Corporate Social Responsibility berpengaruh positif pada abnormal return.

\section{METODE PENELITIAN}

Penelitian ini dilakukan pada perusahaan manufaktur yang terdaftar di Bursa Efek Indonesia (BEI) karena perusahaan yang terdaftar di BEI diwajibkan untuk mempublikasikan laporan keuangan dan laporan tahunan yang memuat informasi mengenai kinerja perusahaan baik itu dari segi keuangan dan non keuangan, sehingga objek yang diteliti dapat diamati. Data diperoleh dengan mengakses web.idx.id dan finance.yahoo.com.

Menentukan actual return atau realized return, yaitu return sesungguhnya yang terjadi. Dihitung dengan menggunakan persamaan:

$$
\mathrm{R}_{\mathrm{i}, \mathrm{t}}=\frac{\mathrm{P}_{\mathrm{t}}-\mathrm{P}_{\mathrm{t}-1}}{\mathrm{P}_{\mathrm{t}-1}}
$$

Keterangan:

$\mathrm{R}_{\mathrm{i}, \mathrm{t}}=$ Return saham tahunan

$\mathrm{P}_{\mathrm{t}}=$ Harga penutupan saham pada tahunke $\mathrm{t}$

$\mathrm{P}_{\mathrm{t}-1}=$ Harga penutupan saham pada tahunke $\mathrm{t}-1$

Menentukan expected return, Expected return merupakan return yang diharapkan oleh investor ketika menanamkan sahamnya. Persamaannya yaitu:

$$
\mathrm{E}\left[\mathrm{R}_{\mathrm{i}, \mathrm{t}}\right]=\frac{\mathrm{IHSG}_{\mathrm{t}}-\mathrm{IHSG}_{\mathrm{t}-1}}{\mathrm{IHSG}_{\mathrm{t}-1}}
$$

Keterangan:

$\mathrm{E}\left[\mathrm{R}_{\mathrm{i}, \mathrm{t}}\right]=$ Expected return tahunan pada periode peristiwa ke- $\mathrm{t}$

$\mathrm{IHSG}_{\mathrm{t}}=\mathrm{Indeks}$ harga saham gabungan pada periode-periode peristiwa ke t $\mathrm{IHSG}_{\mathrm{t}-1}=$ Indeks harga saham gabungan pada periode-periode peristiwa ke $\mathrm{t}-1$ 
Menentukan abnormal return, yaitu selisih antara actual return dan expected return. Dengan persamaan sebagai berikut :

$\mathrm{AR}_{\mathrm{i}, \mathrm{t}}=\mathrm{R}_{\mathrm{i}, \mathrm{t}}-\mathrm{R}_{\mathrm{M}, \mathrm{t}}$

Keterangan:

$\mathrm{AR}_{\mathrm{i}, \mathrm{t}}=$ Abnormal return suatu saham i pada periode ke- $\mathrm{t}$

$\mathrm{R}_{\mathrm{i}, \mathrm{t}}=$ Actual return saham i pada periode ke-t

$\mathrm{R}_{\mathrm{M}, \mathrm{t}}=$ Rata-rata return di pasar beberapa periode sebelumnya (expected return)

Rumus perhitungan CSRI adalah sebagai berikut Sayekti dan Ludovicus (2007):

$\operatorname{CSRIj}=\frac{\sum X_{i j}}{n_{j}}$

Keterangan:

CSRIj :Corporate Social Responsibility Disclosure Index perusahaan j

nj :jumlah item untuk perusahaan $\mathrm{j}, \mathrm{nj} \leq 91$

$\mathrm{Xij}$ :dummy variable: 1 = jikaitem i diungkapkan; $0=$ jikaitem i tidakdiungkapkan.

Menurut Mamduh (2009) ROE diukur dengan menggunakan persamaan sebagai berikut:

$R O E=\frac{\text { Laba Bersih }}{\text { Modal Saham }}$

Menurut Darmadji (2012) PBV diukur dengan menggunakan persamaan sebagai berikut:

$P B V=\frac{\text { Harga Saham }}{\text { Nilai Buku Saham }}$

Populasi dalam penelitian ini adalah seluruh perusahaan manufaktur yang terdaftar di BEI dari tahun 2013 - 2017. Teknik pengambilan sampel dilakukan dengan menggunakan metode purposive sampling yaitu pemilihan secara tidak acak yang informasinya diperoleh dengan menggunakan pertimbangan tertentu.

Teknik analisis yang digunakan dalam penelitian ini adalah analisis regresi linier berganda. Analisis linier berganda adalah pengujian yang dilakukan untuk 
mengetahui ada tidaknya pengaruh atas dua atau lebih variabel independen terhadap variabel dependen. Analisis linier berganda adalah pengujian yang dilakukan untuk mengetahui ada tidaknya pengaruh Corporate Social Responsibility $\left(\mathrm{X}_{1}\right)$ pada abnormal return $(\mathrm{Y})$ dengan $\mathrm{ROE}\left(\mathrm{X}_{2}\right)$ dan $\mathrm{PBV}\left(\mathrm{X}_{3}\right)$ sebagai varibel kontrol. Persamaan regresi linier berganda adalah sebagai berikut :

$\mathrm{Y}=\alpha+\beta_{1} \cdot \mathrm{CSRI}+\beta_{2} \cdot \mathrm{ROE}+\beta_{3} \cdot \mathrm{PBV}+\varepsilon$

Keterangan :

Y :Abnormal Return

$\alpha:$ Konstanta

$\beta_{1,2,3}$ :koefisien regresi pada setiap variabel

CSRI :Corporate Social Disclosure Index

ROE :Return on Equity

PBV :Price to Book Value

$\boldsymbol{E}$ :error term

\section{HASIL DAN PEMBAHASAN}

Berdasarkan hasil uji statistic deskriptif diperoleh sebanyak 300 data observasi yang berasal dari jumlah perusahaan manufaktur yang terdaftar di Bursa Efek Indonesia (BEI) dan konsisten mengungkapkan Corporate Social Responsibility dalam laporan tahunan pada tahun 2013-2017. Sampel yang berjumlah 300 memiliki data yang lengkap untuk kepentingan penelitian. Hasil statistic deskriptif disajikan pada Tabel 1.

Tabel 1.

Hasil StatistikDeskriptif

\begin{tabular}{lrrrrc}
\hline & N & Mean & Std. Deviation & \multicolumn{1}{c}{ Min } & Max \\
\hline CSR & 300 & 0,418 & 0,160 & 0,154 & 0,846 \\
ROE & 300 & 0,069 & 0,228 & $-2,337$ & 1,631 \\
PBV & 300 & 1,427 & 1,567 & $-3,058$ & 8,582 \\
AR & 300 & $-0,006$ & 0,075 & $-0,193$ & 0,366 \\
\hline \multicolumn{2}{l}{ Sumber: Data diolah, 2018 } & & &
\end{tabular}


Berdasarkan Tabel 1 dapat dilihat bahwa variabel Corporate Social Responcibility yang diukur dengan penjumlahan dari setiap item untuk keseluruhan skor perusahaan kemudian dibagi dengan keseluruhan item pengungkapan yang ada dari tahun 2013-2017.

Sampel penelitian variabel pengungkapan Corporate Social Responcibility memiliki skor pengungkapan terendah sebesar 0,15 dan skor pengungkapan tertinggi sebesar 0,846. Rata-rata skor pengungkapan Corporate Social Responcibility yang dilakukan oleh perusahaan sampel sebesar 0,418 atau 41,80 persen dengan standar deviasi sebesar 0,160. Jarak atau rentang variasi pengungkapan CSR data satu dengan yang lainnya sebesar0,160 atau 16 persen, sehingga dapat diartikan bahwa nilai standar deviasi tersebut kurang dari nilai ratarata, yang artinya nilai rata-rata pengungkapan CSR memiliki tingkat penyimpangan yang kecil karena semakin kecil tingkat penyimpangan maka semakin kecil pula variasi datanya.

Selama periode 2013 hingga 2017, ROE dari perusahaan sampel memiliki rata-rata sebesar 0,069 atau 6,9 persen dengan standar deviasi sebesar 0,228 atau 22,80 persen. Standar deviasi yang lebih tinggi dari rata - rata ini menunjukkan bahwa tingkat penyimpangan yang besar artinya semakin besar tingkat penyimpangan, maka variasi dari variabel ROE terbilang tinggi. Pada periode penelitian 2013-2017, tampak bahwa nilai ROE terendah sebesar -2,337 yang merupakan ROE dari PT. Tirta Mahakam Resources Tbk. (TIRT) tahun 2013 karena pada tahun ini perusahaan mengalami kerugian. Sedangkan ROE tertinggi 
sebesar 1,631 yang merupakan ROE dari PT. Bentoel Internasional Investama Tbk. (RMBA) tahun 2014.

Rata-rata PBV adalah sebesar 1,427 dengan standar deviasi sebesar 1,567. Nilai standar deviasi tersebut lebih besar dari rata-rata, sehingga dapat disimpulkan bahwa nilai rata-rata PBV memiliki nilai penyimpangan besar, semakin besar tingkat penyimpangan, maka semakin besar pula variasi datanya. Pada periode penelitian sampel, tampak bahwa nilai PBV terendah sebesar-3,058 yang merupakan PBV dari PT. Bentoel Internasional Investama Tbk. (RMBA )tahun 2014. Sedangkan PBV tertinggi adalah sebesar 8,582 yang merupakan PBV dari PT. Kalbe Farma Tbk (KLBF) tahun 2014. Nilai PBV yang tinggi dari KLBF ini disebabkan karena nilai buku per saham jauh lebih rendah dibandingkan harga dipasar.

Rata-rata abnormal return adalah sebesar-0,006 dengan standar deviasi sebesar 0,0756. Standar deviasi yang lebih tinggi dari rata - rata ini menunjukkan bahwa tingkat penyimpangan yang besar artinya semakin besar tingkat penyimpangan, maka variasi dari variabel abnormal lreturn terbilang tinggi. Pada periode penelitian sampel, tampak bahwa nilai abnormal return terendah sebesar0,193 dari PT. Ekadharma International Tbk (EKAD) tahun 2013. Abnormal return yang bernilai negative dapat diartikan bahwa ternyata return yang didapatkan oleh investor lebih kecil dari pada return yang diharapkan. Abnormal return tertinggi yaitu sebesar 0,366 yang merupakan abnormal return dari PT. Tirta Mahakam Resources Tbk (TIRT) tahun 2015. Perusahaan tersebut memiliki abnormal return 
yang bernilai positif dapat diartikan bahwa return yang didapatkan oleh investor lebih besar dari return yang diharapkan.

Pengujian normalitas data pada penelitian ini menggunakan metode Kolmogorov-Smirnov. Apabila Asmyp.Sig (2-tailed) lebih besar dari level of significant yang dipakai (5\%), maka data populasi dikatakan berdistribusi normal.

Tabel 3.

\section{Hasil Uji Kolmogorov-Smirnov}

\begin{tabular}{cllll}
\hline No. & Uraian & $\begin{array}{l}\text { Koefisien Kolmogorov- } \\
\text { Smirnov }\end{array}$ & Sig. & Keterangan \\
\hline 1. & CSR & 0,132 & 0,000 & Tidak Normal \\
2. & ROE & 0,183 & 0,000 & Tidak Normal \\
3. & PBV & 0,199 & 0,000 & Tidak Normal \\
4. & AR & 0,135 & 0,000 & Tidak Normal \\
\hline
\end{tabular}

Berdasarkan Tabel 3 hasil uji normalitas diperoleh nilai Asmyp.Sig (2tailed) 0.000 disemua variabel. Namun hal ini bukan menunjukkan bahwa data tidak terdistribusi secara normal, akan tetapi karena dalam penelitian ini sampel yang digunakan banyak (Purnaningsih, 2018). Dalam penelitian ini menggunakan 300 sampel maka tidak diperlukan uji normalitas sebab data sudah dapat diasumsikan berdistribusi normal.

Uji one sample t-test merupakan bagian dari statistic parametrik. Oleh karena itu asumsi dasar yang harus terpenui adalah data penelitian berdistribusi normal. Dasar pengambilan keputusan uji one sample t-test jika nilai Sig. (2tailed) $<0,05$, maka Ho ditolak dan jika nilai Sig. (2-tailed) $>0,05$, maka Ho diterima. Hasil uji one sample t-test disajikan pada Tabel 4. 
Tabel 4.

Hasil Uji One Sample T-Test

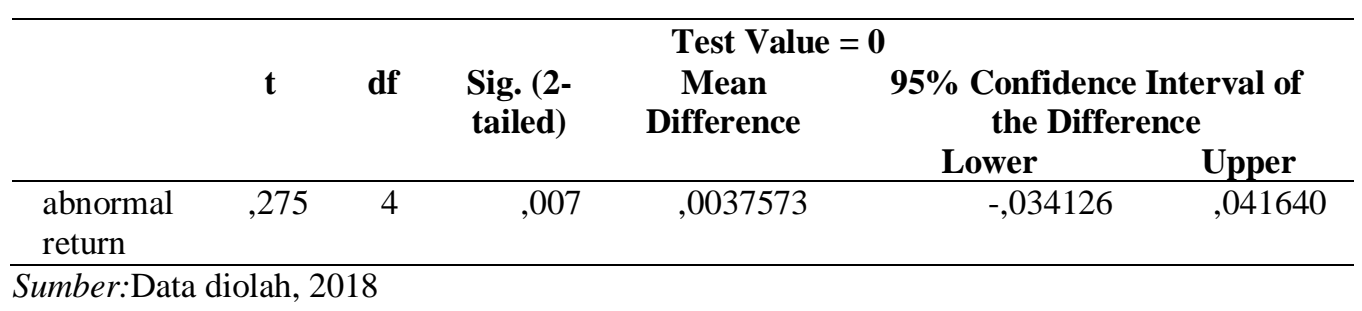

Dari hasil uji one sample t-test diketahui bahwa dengan nilai signifikansi sebesar $0,007<0,05$ yang berarti bahwa Ho ditolak dan Ha diterima, sehingga dapat diartikan bahwa nilai abnormal return tidak sama dengan nol dan memiliki pengaruh teradap variabel yang ditetili.

Uji multikolinearitas digunakan untuk menguji apakah dalam model regresi ditemukan adanya korelasi antar variabel bebas. Jika nilai toleransi lebih dari $10 \%$ atau VIF kurang dari 10 maka dikatakan tidak ada multikolinearitas. Hasil uji multikolinearitas disajikan pada Tabel 5.

Tabel 5.

\section{Hasil Uji Multikolinearitas}

\begin{tabular}{ccc}
\hline Variabel & Tolerance & VIF \\
\hline CSR & 0,934 & 1,070 \\
ROE & 0,965 & 1,037 \\
PBV & 0,965 & 1,036 \\
\hline
\end{tabular}

Sumber: Data diolah, 2018

Berdasarkan hasil analisis, menunjukkan bahwa masing-masing variabel memiliki nilai VIF dibawah 10 dan nilai tolerance di atas 0,10 yang berarti bahwa tidak terjadi multikolonieritas antar variabel independen dalam analisis. Dari hasil uji ini korelasi antar variabel independen tidak terdapat korelasi.

Uji heteroskedastisitas bertujuan untuk menguji apakah model regresi terjadi ketidaksamaan varians dari residual pengamatan kepengamatan yang lain. 
Jika tingkat signifikansi berada di atas 0,05 maka model regresi ini bebas dari masalah heteroskedastisitas. Hasil uji heteroskedastisitas disajikan pada Tabel 6.

Tabel 6.

Hasil Uji Heteroskedastisitas

\begin{tabular}{lll}
\hline Variabel & Sig. & Keterangan \\
\hline CSR & 0,253 & Bebasheteroskedastisitas \\
ROE & 0,281 & Bebasheteroskedastisitas \\
PBV & 0,992 & Bebasheteroskedastisitas \\
\hline
\end{tabular}

Sumber:Data diolah, 2018

Dari hasil Uji Glejser pada Tabel 6 dapat dilihat bahwa nilai signifikansi masing-masing variabel lebih besar dari 0,05 sehingga dapat disimpulkan bahwa dalam model regresi tidak terjadi heteroskedastisitas.

Analisis linier berganda adalah pengujian yang dilakukan untuk mengetahui ada tidaknya pengaruhCorporate Social Responsibility $\left(\mathrm{X}_{1}\right)$ pada abnormal return (Y) dengan ROE $\left(\mathrm{X}_{2}\right)$ dan PBV $\left(\mathrm{X}_{3}\right)$ sebagai varibel kontrol.

Tabel 7.

Hasil AnalisisRegresi Linier Berganda

\begin{tabular}{|c|c|c|c|c|c|c|}
\hline \multirow{2}{*}{\multicolumn{2}{|c|}{ Model }} & \multicolumn{2}{|c|}{$\begin{array}{l}\text { Unstandardized } \\
\text { Coefficients }\end{array}$} & \multirow{2}{*}{$\begin{array}{c}\text { Standardized } \\
\text { Coefficients } \\
\text { Beta } \\
\end{array}$} & \multirow[t]{2}{*}{$\mathbf{T}$} & \multirow[t]{2}{*}{ Sig. } \\
\hline & & B & Std. Error & & & \\
\hline \multirow[t]{4}{*}{1} & (Constant) & 0,004 & 0,012 & & 0,332 & 0,740 \\
\hline & CSR & 0,021 & 0,028 & $-0,044$ & 0,750 & 0,044 \\
\hline & $\mathrm{ROE}$ & $-0,057$ & 0,019 & $-0,171$ & $-2,932$ & 0,004 \\
\hline & PBV & 0,001 & 0,003 & 0,030 & 0,515 & 0,607 \\
\hline \multicolumn{2}{|c|}{ Adjusted $\mathrm{R}^{2}$} & & & & & 0,124 \\
\hline \multicolumn{2}{|c|}{ F Hitung } & & & & & 3,447 \\
\hline \multicolumn{2}{|c|}{ Sig. F } & & & & & 0,017 \\
\hline
\end{tabular}

Berdasarkan hasil yang diperoleh pada koefisien hasil regresi pada Tabel 7 adalah:

$$
\mathrm{Y}=0,004+0,021 \mathrm{CSRI}-0,057 \mathrm{ROE}+0,001 \mathrm{PBV}+\varepsilon
$$

Berdasarkan hasil uji koefisien determinasi pada Tabel 7 menunjukkan bahwa nilai adjusted $\mathrm{R}$ square model sebesar 0,124 yang berarti bahwa 
12,4 persen variabel abnormal return dapat dijelaskan oleh variabel pengungkapan CSR, ROE,dan PBV. Sedangkan sisanya sebesar 87,6 persen dijelaskan oleh variabel lainnya yang tidak dimasukkan dalam model regresi.

Berdasarkan hasil perhitungan uji $\mathrm{F}$ pada Tabel 7 yaitu hasil analisis regresi linier berganda menunjukkan nilai dari uji F sebesar 0,017 yang lebih rendah dari pada level signifikansi 0,05 maka artinya bahwa model regresi layak untuk digunakan. Sehingga variabel CSRI, ROE, dan PBV secara bersama-sama memiliki pengaruh signifikan pada abnormal return.

Hasil uji statistik t untuk variabel pengungkapan CSR yang ditunjukkan dengan CSR menunjukkan nilai signifikansi sebesar 0,044 $<0,05$ yang berarti bahwa Ho ditolak dan Ha diterima, sehingga Variabel pengungkapan CSR berpengaruh positif pada variabel abnormal return.

Hasil uji statistik t untuk variabel ROE dengan nilai signifikansi sebesar 0,004 $<0,05$ yang berarti bahwa Ho ditolak dan Ha diterima, sehingga variabel ROE berpengaruh pada Variabel abnormal return.

Hasil uji statistik t untuk variabel PBV dengan nilai signifikansi sebesar yang ditunjukkan dengan CSR menunjukkan nilai signifikansi sebesar 0,607 >0,05 yang berarti bahwa Ho diterima dan Ha ditolak, sehingga variabel PBV tidak berpengaruh pada Variabel abnormal return.

Hasil pengujian menunjukkan, pengungkapan CSR berpengaruh positif pada abnormal return. Hasil analisis ini mengindikasikan bahwa investor di Indonesia sudah mulai menggunakan informasi pengungkapan CSR dalam melakukan keputusan investasi. Hal ini menunjukan bahwa pasar modal Indonesia 
sedang mengarah atau mengikuti trend global, dimana tema-tema CSR sudah menjadi salah satu sumber pengambilan keputusan investasi bagi investor.

Penelitian ini sejalan dengan penelitian terdahulu. Beberapa diantaranya adalah penelitian Cheng dan Christiawan (2011), Nugraha dan Juniarti (2015), dan Yulia dan Wahidhwati (2013). Hasil penelitian ini menunjukan bahwa informasi CSR yang diungkapkan perusahaan direspon baik oleh investor yang ditunjukan dengan adanya abnormal return.

Pengungkapan CSR yang dilakukan perusahaan memiliki kandungan informasi, sehingga memeberikan sinyal kepada investordan akan bereaksi pada pengungkapan tersebut. Pengungkapan aktivitas perusahaan yang berkaitan dengan CSR dapat mengirimkan signal positif kepada stakeholders dan pasar mengenai prospek keberlangsungan hidup perusahaan dimasa yang akan datang.

Hasil penelitian ini memberikan tambahan informasi mengenai bagaimana pengaruh pengungkapan CSR terhadap abnormal return dengan ROE dan PBV sebagai variabel kontrol. Dalam teori signaling yang menyebutkan bahwa perusahaan yang berkualitas baik akan sengaja memberikan sinyal kepada pasar, dan memberikan informasi mengenai keadaan perusahaan yang berdampak bagi kelangsungan hidup perusahaan, dikarena pengungkapan CSR berpengaruh terhadap abnormal return maka dapat menjadi sinyal bagi para investor untuk berinvestasi dalam perusahaan karena perusahaan telah mengungkapkan CSR dalam annual report. Dikarenakan dalam teoristakeholder menyatakan bahwa perusahaan bukanlah entitas yang hanya beroperasi untuk kepentingan sendiri, namun harus memberikan manfaat kepada seluruh stakeholder-nya. Sehingga para 
stakehorlder dapat mengevaluasi sejauh mana perusahaan telah melaksanakan perannya sesuai keinginan stakeholder dengan investor yang berinvestasi karena perusahaan yang mengungkapkan CSR dalam annual report.

Implikasi dari penelitian ini yaitu pengungkapan CSR dalamannual report mencerminkan kondisi serta prospek perusahaan dimasa mendatang, sehingga investor menggunakan pengungkapan CSR dalam pengambilan keputusan untuk berinvestasi. Hal ini dapat meningkatkan motivasi perusahaan dalam mengungkapkan CSR yang telah dilakukan. Selain itu, investor juga lebih menyadari pentingnya isu CSR di masa depan, sehingga akan meningkatkan kesadaran perusahaan untuk mengimplementasikan aktivitas CSR dengan memaksimalkan dampak positif serta meminimalkan dampak negative dari kegiatan tersebut.

\section{SIMPULAN}

Berdasarkan hasil pembahasan penelitian ini, maka dapat disimpulkan bahwa pengungkapan CSR berpengaruh positif pada abnormal return. Investor menaruh perhatian terhadap aktivitas tanggungjawab sosial perusahaan dalam memutuskan untuk berinvestasi. Tinggi rendahnya pengungkapan CSR ternyata dipergunakan investor dalam mempertimbangkan keputusannya dalam berinvestasi.

Berdasarkan simpulan tersebut, maka disaran bahwa dengan dibuktikannya CSR berpengaruh positif pada abnormal return, maka sebaiknya perusahaan semakin menyadari pentingnya pengungkapan informasi CSR pada laporan 
tahunannya dengan memperhatikan kelengkapan informasi yang diungkapkan mengenai CSR. Agar didapatkan hasil yang lebih akurat, perusahaan harus terus mengikuti perkembangan yang ada terkait dengan CSR, sehingga menjadi salah satu pertimbangan investor untuk berinvestasi kedalam perusahaan.

\section{REFERENSI}

Anugrawati, Mirna Arsita. (2015). PengaruhPengungkapan Corporate Social Responsibility dan InformasiKeuanganTerhadap Abnormal Return. JurnalIlmu dan RisetAkuntansi. 4(6).

Atiqah. (2016). PengaruhPengungkapanTanggungJawabSosialPerusahaan Terhadap Tingkat PengembalianSaham. Akuntabilitas: JurnalIlmuAkuntansi. P-ISSN: 1979-858X; E-ISSN: 2461-1190. 9(2), pp:215-230.

Brigham dan Houston. (2009). Dasar-dasarManajemenKeuangan, (Edisi Kesepuluh). Jakarta: SalembaEmpat.

Chen, Yi-Chun,.MingyiHung,. dan Yongxiang Wang. (2018). The effect of mandatory CSR disclosure on firm profitabilityand social externalities: Evidence from China. Journal of Accounting and Economics. 65. Pp:169190.

Cheng, Megawati dan Yulius Jogi Christiawan. (2011). PengaruhPengungkapanCorporate Social Responsibility terhadap Abnormal Return. JurnalAkuntansidan Keuangan.13(1). Pp. 23-35.

Darmadji, Tjiptono, dan Fakhruddin. (2012).Pasar Modal di Indonesia (Edisiketiga).Jakarta: SalembaEmpat.

Global Reporting Initiative. (2013). Prinsip-PrinsipPelaporan dan PengungkapanStandar.

https://www.globalreporting.org/resourcelibrary/Bahasa-Indonesia-G4Part-One.pdf. Diunduh 2 Juni 2018.

Hartono, Jogiyanto. (2015). TeoriPortofolio dan AnalisisInvestasi (EdisiKesepuluh). Yogyakarta: Yogyakarta. 
Indrawati, N. (2009). Pengungkapan Corporate Social Responsibility (CSR) dalam Annual Report sertaPengaruh Political Visibility dan Economic Performance. PekbisJurnal. 1(1), 1-11.

Kastutisari, Savitri. dan Nurul Hasana UD. (2012). PngaruhPengungkapanCorporate SocialResponsibility (CSR) TerhadapAbnormal Return. Surabaya: STIE Perbanas Surabaya.hal: 102121.

Mamduh M. Hanafi dan Abdul Halim. (2009). AnalisisLaporanKeuangan. Yogyakarta: UPPSTIM YKPN.

Muid, Dul. (2011). Pengaruh Corporate Social Responsibility Terhadap Stock Return (StudiEmpiris Perusahaanyang Terdaftar di BEI Tahun 2008-2009). FokusEkonomi. 6(1). Hal: 105-121.

Mujiani, Sari. (2017). Determinan Abnormal Return Dengan Corporate Social Responsibility SebagaiPemediasi Pada Perusahaan Yang Terdaftar Di Bursa Efek Indonesia. Tesis. Program PascaSarjana Magister AkuntansiUniversitas Pancasila.

Nugraha, Dessy Arta dan Juniarti. (2015). Pengaruh Corporate Social Responsibility TerhadapRespon Investor Pada SektorIndustriPertambangan. Business Accounting Review. 3 (1), pp: 133143.

Purnaningsih, Deni. (2018). PengaruhCorporate Social ResponsibilityTerhadapKinerjaKeuangan Pada Perusahaan Manufaktur Yang Terdaftar Di Bursa Efek Indonesia (BEI). Skripsi. Universitas Islam Indonesia FakultasEkonomi Yogyakarta.

Suharto, Edi. (2010). CSR dan COMDEV InvestasiKreatif Perusahaan di Era Globalisasi. Bandung :Alfabeta

Tan, Andreas., DesmiyawatiBenni., dan WardaLiani. (2016). Determinants of Corporate Social Responsibility Disclosure andInvestor Reaction. International Journal of Economics and Financial Issues. 6(S4) 11-17.

Yulia,Vivi Indah dan Wahidahwati. (2013). PengaruhPengungkapanCorporate Social Responsibility Terhadap Abnormal Return. JurnalImu\&RisetAkuntansi. 2 (3). 